\title{
Identifying Key Factors Affecting Integrated and Sustainable Development of Red Onion Horticulture Cluster Area
}

\author{
Helmi $^{\# 1}$, Rafnel Azhari ${ }^{\# 2}$, Henmaidi ${ }^{*}$, Silfia $^{+3}$, and Ibnu Riyadhie ${ }^{+4}$ \\ \# Department of Socio-economic of Agriculture, Faculty of Agriculture, Andalas University, Padang 25163, Indonesia. \\ Email:1helmi@agr.unand.ac.id; ${ }^{2}$ rafnelazhari@agr.unand.ac.id
}

*Department Industrial Engineering, Faculty of Engineering, Andalas University, Padang 25163, Indonesia. Email: henmaidi@ft.unand.ac.id

${ }^{+}$Graduate Program of Andalas University, Padang 25163, Indonesia.

Email: ${ }^{3}$ silfiasukri@gmail.com; ${ }^{4}$ ibnuriyadhieprayanda@gmail.com

\begin{abstract}
Sustainable development of small-scale horticulture farming is very much determined by how these farmings develop and organized into an integrated agriculture cluster area which aims at fulfilling human needs, equitable distribution of economic benefits, and participation of farmers and rural people in the dynamics of development. Indonesia has adopted it as policy but with limited evidence of successful implementation because of the ecosystem for agriculture cluster area development not yet existed. Despite the ecosystem not yet developed, small-scale farmers continue to manage their farming to support their livelihood. In this context, there is a need to develop an alternative enabling framework based on an understanding of the dynamics of horticulture farming. The objectives of this research are to understand the dynamics of the red onion horticulture farming, assessing key factors affecting farming management, and identify elements of a framework for developing integrated small-scale red onion farming cluster area based on the key factors identified. A mix research method was applied: an in-depth interview and survey. The results of the research indicated that the following key factors affecting the dynamics of small-scale red onion farming: (1) market, product distribution, and price fluctuation; (2) provision of agriculture extension services and consideration to use inputs; (3) existence and functionality of farmers' group (organization); (4) source of capital and the used of financial service industry; (5) supports from government program; (6) infrastructures to support farming activities (in term of farms access road and water); (7) mutually beneficial synergy and partnership among the stakeholders; and (8) digital platform to facilitate interaction among stakeholders. These key factors would form the basis to develop an alternative framework for integrated agriculture are development.
\end{abstract}

Keywords - sustainable development; agriculture cluster area; small-scale horticulture farming; social capital; agriculture extension.

\section{INTRODUCTION}

Sustainable agriculture and sustainability of benefits stream from development projects have become a concern for decades. Sustainable agriculture development concept has three inter-related aspects: economic, social, and environmental with the goals improving the well-being of the farmers and other related stakeholders. The efforts to achieve the goals require an integrated approach given the inter-related nature of the three aspects. This study is embarking from the complex problems facing by small-scale red onion horticulture farmers along the value chain (from production to distribution of produce) which negatively affect their effort to improve their household economy. The scale of farming which is small in scale is one of the key features of agriculture development in Indonesia. These complex problems together with the scale of farming need to take into account in improving the livelihood of small farmers. Red onion farmers in Highland District of Solok, West Sumatra, is one of the farming communities facing this kind of problems. This research focuses on identifying key factor related to sustainable development of integrated agriculture cluster area.

Organizing the small farms into an agriculture cluster area is one option to deal with the problems. Agriculture cluster area development is a generic concept which in practice has been given various names such as agropolitan and agriculture production center. The concept of integrated agriculture cluster area development firstly introduced in 1975 by using the term of agropolitan, which substantially is about the spatial framework for accelerating agriculture, local resources management and rural development [1]. The aim of the agropolitan development is to fulfill human needs, 
equitable distribution of economic benefits, and participation of farmers and rural people in the dynamics of development.

A historical review of experiences with regard to agriculture cluster area development in Indonesia, found out that [2]: (1) Indonesia has had some experiences with agriculture cluster area development project; (2) the achievement were not as expected because implementation used partial and project approaches, the dominant roles of the government agency and no long-term management; and (3) this project setting made the activities time-bounded, limited aspects covered and unsustainable; (4) limited public funding available (and tended to be declining) to support the implementation, made achievement was limited. All of these findings explained why limited evidence available about successful implementation of agriculture cluster area (agropolitan) development project [3]. A study on strategies of agropolitan development also found that there was a gap between planning and implementation which made the objective of development not fully achieved [4]. Even though there is a district government policy for agropolitan area development; however, based on the index calculated the level of achievement was low [5].

In addition to the problem with management approach, there is a need for the government to provide firm policy support to small farmers to be an integrated part of synergy and partnership in the agriculture cluster area development, which in the past, was not the case [6], [7]. Another study on carrot and chili pepper horticulture produces also found that the farmers did not get price protection [8]. In term of red onion farming, some studies indicated that the farmers did not gain significant profit even though retail price relatively high because of the long marketing chain [9]. Marketing problem related to agriculture produce was also faced by the agropolitan farmers in Yogyakarta, Indonesia, so that the development of the agropolitan area has not had the significant impact on the livelihood of the farmers [10]. Similar marketing and market access problem was also experienced by farmers in Thailand [11].

Some studies pointed out the need to strengthen the bargaining position of the farmers through institutional approach by developing and building the capacity of farmers' (producers) organization [12]-[16]. Another aspect related to the strengthening of farmers position in the market of produce is information management and application of IT [17], [18]. Access to information and IT is related to production management and application of technology was also found important to support small-scale farmers [11], [18]. Agglomeration of activities, capacity building of the farmers and rural people, supportive government policies, and participatory and inclusive approach are important in the development of agropolitan (integrated agriculture cluster) area [19].

A review of concepts, principles and global evidence on the sustainability of agriculture, concluded that it is concerned about the development of technologies and practices which do not affect the environment, accessible to the farmers and effective in usage, and improvement of agriculture productivity [20]. This review did not include concern about fair market relation and distribution of agriculture produce but stressed the need to put attention to the concept of multi-functionality of agriculture and the costs related to the used of external inputs. A proposal has been made to move toward agricultural sustainability based on 'bio-village' paradigm which emphasized the importance of eco-friendly agriculture which promoted along with the development of on- and non-farm eco-enterprises based on sustainable management of natural resources [21]. This will need support from ICT-based village knowledge and innovation management.

At the global level, United Nations has declared Sustainable Development Goals (SDGs) which consist of seventeen (17) goals as the reference for countries to make their development more sustainable. Among the seventeen goals, Goal \#2 is clearly stated sustainable agriculture: End hunger, achieve food security and improved nutrition and promote sustainable agriculture. Other goals from the SDGs which related to the focus of this research are: Goal \#1 on poverty alleviation; Goal \#6 about water management; Goal \#8 on inclusive and sustainable economic growth, full and productive employment and decent work; Goal \#9 about fostering application of innovation, in this case in agriculture production and agribusiness; Goal \#13 about climate change and its impacts; Goal \#15 about rehabilitation and conservation of agriculture resources; Goal \#16 on the development of inclusive institution including at local level; and Goal \#17 about building partnership for sustainable (agriculture) development.

Despite the existence of those problems, challenges and future agenda, small-scale farmers have to continue to manage their horticulture farming to support their livelihood. As far as the results of research conducted in Indonesia [2][13], [18], [19], indicated that some key factors for the development of integrated agriculture cluster area were not yet there, in another word the ecosystem has not been developed. In this context, there is a need to understand and identify key factors affecting the development of the agriculture cluster area from the farmer's point of view. This understanding would provide a basis to develop the alternative enabling framework and setting toward strengthening small-farmers position in sustainable livelihood and horticulture farming development.

There is three objects of this research: (1) to understand the dynamics of the red onion horticulture farming; (2) to identify key factors affecting farming management; and (3) identify elements of the framework for developing integrated small-scale red onion farming cluster area based on the key factors identified.

\section{MATERIAL AND METHODS}

\section{A. Research Site.}

The research was conducted in Solok District, West Sumatra Province, Indonesia, which is one of the production center of red onion in Indonesia (besides Brebes in Java). Since 2013, the Government of West Sumatra Province has formally declared cluster area approach in agriculture development, and Solok District one of the horticulture cluster area. Solok District consists of 14 sub-districts which 4 of them located in the highland, namely: Lembah Gumanti, Danau Kembar, Lembang Jaya, and Talang Mountain (see Map of Solok District). 


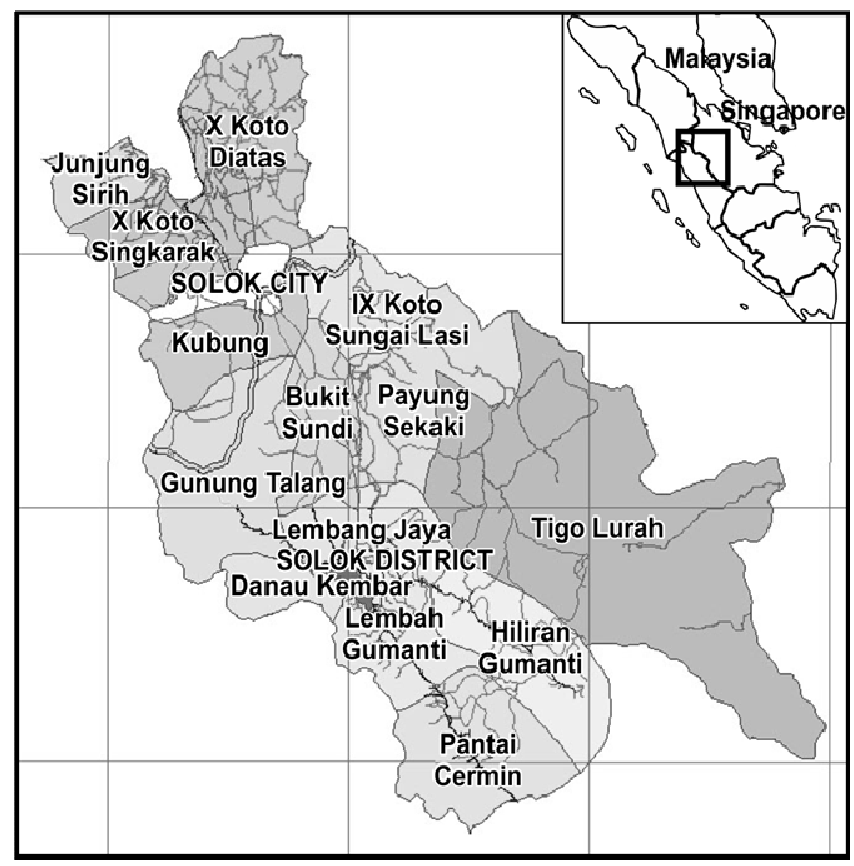

Fig. 1 Map of Solok District

These four sub-districts has included among horticulture production center areas of West Sumatra Province in 2013. The biggest production center of the red onion crop located in the Lembah Gumanti Sub-district with 5,051 Ha or 63.8 percent of the total planting area, which dominated by two villages: Sungai Nanam and Alahan Panjang, where the research conducted (see Table 1).

TABLE I

RED ONION CROP PLANTING AREA, PRODUCTION, AND PRODUCTIVITY IN SOLOK DISTRICT, 2017

\begin{tabular}{|l|r|r|r|}
\hline Subdistrict & $\begin{array}{c}\text { Planting/ } \\
\text { Harvested } \\
\text { Area (Ha) }\end{array}$ & $\begin{array}{c}\text { \% of Total } \\
\text { Planting } \\
\text { Area }\end{array}$ & $\begin{array}{l}\text { Production } \\
\text { (Ton) }\end{array}$ \\
\hline 1. Pantai Cermin & $482 / 479$ & 6.1 & $3,912.0$ \\
\hline 2. Lembah Gumanti & $5,051 / 4,655$ & 63.8 & $55,077.0$ \\
\hline 3. Hiliran Gumanti & $129 / 122$ & 1.6 & $1,182.7$ \\
\hline 4. Payung Sekaki & $255 / 255$ & 3.2 & $2,490.1$ \\
\hline 5. Tigo Lurah & $6 / 6$ & 0.1 & 38.2 \\
\hline 6. Lembang Jaya & $896 / 858$ & 11.3 & $10,202.4$ \\
\hline 7. Danau Kembar & $664 / 567$ & 8.3 & $6,183.1$ \\
\hline 8. Gunung Talang & $182 / 207$ & 2.3 & $1,862.8$ \\
\hline 9. Bukit Sundi & $4 / 6$ & 0.05 & 31.5 \\
\hline 10. IX Koto S. Lasi & 0 & 0 & 0 \\
\hline 11. Kubung & $18 / 19$ & 0.23 & 146.6 \\
\hline 12. X Koto Diatas & $5 / 4$ & 0.1 & 22.5 \\
\hline 13. X K. Singkarak & $30 / 29$ & 0.4 & 241.9 \\
\hline 14. Junjung Sirih & $197 / 164$ & 2.5 & $1,294.4$ \\
\hline Total & $7,919 / 7,340$ & 100 & $82,685.2$ \\
\hline
\end{tabular}

Source: Solok District Agriculture Agency (2017).

Altitude of highland part of the district area ranging from $329-1,458$ meter above sea level. About half of the area (50.52 percent) having slope more than 16 percent. The climate type falls into E2 according to Oldeman's Category with yearly rainfall ranging from $1,921-2,447 \mathrm{~mm}$ per year, 187 rainy days per year, and the temperatures ranging from $12^{0}-33^{0}$ Celcius.

\section{B. Methods.}

In order to achieve the objective mix methods were used: scoping activity and survey. Scoping of dynamics and issues related to red onion farming and identify concerns and key factors related to the complex problems of red onion farming were conducted by using an in-depth interview with the key informants of stakeholders (farmer group, trader, extension worker, and owner of a kiosk selling agriculture inputs). The in-depth questions addressed to the farmers focus on the problems they were facing and concerns related to the improvement of their red onion farming management while question to other stakeholders focused on their interaction with the farmers. The survey involved sixty farmers to assess key factors affecting red onion horticulture farming management. The farmers involved in the survey were selected randomly from two villages of red onion production center in Lembah Gumanti Subdistrict (Alahan Panjang and Sungai Nanam). The data obtained from the scoping activity was analyzed qualitatively, and the key factors identified as affecting dynamics of red onion farming management is used to construct the questionnaire for the survey. The data from the survey was analyzed using descriptive statistics.

\section{RESULT AND DISCUSSION}

\section{A. Key Factors Affecting Dynamics of Red Onion Horticulture Farming Management.}

The scoping activity has helped to understand the dynamics of red onion farming management. There were two major concerns of the farmers. The first is about climate, the use of chemical pesticides, and irrigation water. This concern are closely related to the successful harvest of red onion crop. When rain comes and the air condition was misty (foggy), they would need to used pesticides to protect the onion crop from attacking by pests and diseases. It was related to the cost of production, the more they use chemical pesticides, the higher the cost of production. The pesticides cost consist of around fifty percent of production cost, and in some cases, if there were more rain and misty conditions happened, they applied more frequent pesticides treatment to the crop. Irrigation water was needed during the dry season as the crop would not properly grow with insufficient water and reduced volume of harvest and quality of product. The second concern was about the price of red onion produce and marketing. The price tended to fluctuate and the farmers got a lower price because of the long marketing chain.

Based on the two major concerns, the associated key factors were also identified. Those key factors are as follow: (1) market, distribution of red onion produce, and price fluctuation; (2) provision of agriculture extension services and consideration to use inputs; (3) existence and functionality of farmers' group (organization); (4) source of capital and the users of financial service industry (credit scheme from the bank); (5) supports from government program; (6) infrastructures to support farming activities (in term of farms access road and water); (7) digital platform to facilitate marketing, agriculture extension, and provision of program for public support, and access to finance; and (8) lack of synergy among the stakeholders. Based on the key factors identified a survey was conducted to obtain data on the experimental condition of red onion horticulture farming 
management. In the next section, the characteristics of the respondents and the results of the survey are presented.

\section{B. Characteristics of Respondents.}

The respondent for the survey has the following characteristics: (1) mostly male (70 percent) and 30 percent female; (2) the dominant education background are junior and senior high school (66.7 percent), the rest is elementary and higher education; (3) in term of age, most of the respondents having age between 15 - 44 years ( 65 percent), followed by the age of $45-59$ years ( 30 percent), and the rest with the age of 60 and above; and (4) in term of marriage status and number of household members, 15 percent of the respondent still single, 68.3 percent with $1-4$ family members, and the rest (16.7 percent) with 5 or more family members.

One interesting characteristic of the respondents is in term of age which predominantly young age (15 - 44 years) which indicated that more young people involved with the red onion horticulture farming.

\section{Survey Results.}

1) The market, distribution of agriculture produce, and price fluctuation: These bundle of issues is one of the most concerned to the farmers. Market institution and product distribution of the red onion is complex involving the farmers and different level of traders from village collectors, local market retailers, intercity traders, wholesalers, and consumers. Most of the farmers (80.3 percent) sell the onion produce at home or in the field, and the rest took it to the local market. Village collectors would actively look for red onion produce when there was order from intercity traders with the agreed price. The village collectors would be offered the farmers a price higher than the price agreed with intercity traders in order to accumulate the volume of red onion collection as ordered by intercity traders.

The selling of the onion produce done by the farmers individually, there was no organized group selling yet to get a better price. There is also another intervening factor related to the product price which is climate change whereby there was no clear pattern of a rainy and dry season. In the dry season, water availability was not sufficient for the crop which affecting productivity and quality of the red onion produced. In the rainy season, because of the wet and foggy conditions, the crop needs persistent chemical pesticides treatment which increased the cost of production. The climate changes have affected the growth of the crop, harvest volume, and quality of produce which, in turn, determined the available supply of the product in the market. These complex situations and interactions would affect red onion produce price.

The price would fluctuate when demand against supply was not matching. Time series data (for 11 years: 2006 2017) showed that the lowest price could go as low as IDR. 4,000/kg (was happening in June and August 2007) and as high as IDR 33,750/kg (was happening in August 2013). A calculation from the farming survey data showed that the break event point (BEP) of production cost was at the IDR. 10,500 per $\mathrm{kg}$. The expectation of lowest level price from the farmers was at IDR 12,000 per kg.
The complexity of the market and price fluctuation added when the interest of the intercity traders is coming in. Shortage of supply at the local market, because it was not harvest time yet, would drive increased in price. The intercity traders saw this as an opportunity to gain profit when the margin by bringing in (importing) the red onion product from outside production center (in this case from Brebes, Java) was there. Increased in supply in the local market would drive the price down which affect the local farmers at the time they harvested their red onion crop. This situation gave another opportunity for the traders to gain profit by absorbing farmers' red onion produced with lower price and sell it to the neighboring provinces market.

2) Provision of agriculture extension services and consideration to use inputs: According to government regulation, there are three institutions having tasks to provide agriculture extension services to the farmers: government/public institution through field extension worker, private institution through its technical staff working to promote the sales of their agriculture inputs products (such as pesticides, fertilizer, and seeds), and local farmers' organization through its self-help extension worker. University (higher education institutions) which have a mandate to provide community services through the researchers, to some extent, were also involved with the provision of extension services related to knowledge and technology developed through research.

Provision of public/government agriculture extension handled by the Lembah Gumanti Sub-district Extension Office which having nine extension workers and 86 units of Farmers Organization (Group) which most of them set up in the Alahan Panjang and Sungai Nanam Village (61 units). Farmers Organizations is also encouraged to form Association of Farmers Groups of which there are six units associations have been set up in the Lembah Gumanti Subdistrict. The sample for the survey was selected from the farmers in Alahan Panjang and Sungai Nanam Village.

Considering the scale of the horticulture, especially red onion crop in the highland of Solok District, there are at least 13 private companies operating in the area selling chemical inputs. These companies also assigned their field sales and extension staff to work in the area. The companies selling chemical inputs are working with local kiosks to distribute the products. Some form of competition also exists among the companies in promoting and selling their products to the farmers. One of the tendency was for the farmers to use more chemical pesticides related to environmental concerns.

Provision of agriculture extension service by the government tended to decline. Since 2017, a technical implementation unit of agriculture at subdistrict level as the arm of Solok District Agriculture Agency has been dissolved. However, the assignment of extension workers in the field still maintained but with minimum support for operational costs.

In term of practical farming activities, there is a variation of respondents' engagement with those type of extension workers. All of the respondents (100 percent) have experience interacting with the private institution extension workers. Interaction with self-help extension workers was second after a private extension worker (75 percent). Engagement of farmers with university researchers was in 
third place (21.7 percent). While interaction with the public extension worker mostly about the matters related to farmers' organization in the context of implementing government tasks and reporting.

It is interesting to note that the role of public extension workers was very minimum while the role of private extension workers was very active in the field in helping developed farmers' knowledge and practical skill related to the use of their products, especially those of chemical pesticides. In the context of the role of the private extension workers, the respondents indicated that their consideration to use inputs (especially chemical inputs) were mostly based on their own experience and advice from the private extension workers. It is also interesting to put attention about the role of the university in agriculture extension related to researchbased extension activities, especially related to transition toward healthy agriculture. However, there is a need to link applied research activities with the overall effort to develop integrated agriculture cluster area.

3) The existence and functionality of farmers' group or organization (social capital development: The setting up of farmers' group is essential to help them better organized (bonding social capital) and strengthen the capacity of the farmers in managing their farms. In addition to that, the farmers' organization could facilitate them to interact with other local organizations closely related to their farming management (bridging social capital) and interacting with the government and market (private) organizations (linking social capital). However, the data from respondents indicated that farmers' organization recognized as not existed (28.3 percent) or formally existed but not functional (71.7 percent) in the context of red onion farming management.

4) The source of capital and the used of the financial service industry (credit scheme): Financial literacy and the used financial service industry is important to support sustainable horticulture farming. Financial literacy of the farmers was not well developed and an only a small number of them was having a bank account (18.3 percent), while the majority (71.7 percent) did not. Most of the farmers used their capital to finance their farming activities (93.7 percent), and an only a small proportion (6.7 percent) used credit scheme or accessing fund from outside the household. Most of the farmers reserved part of the revenue from the selling of their red onion horticulture produce from the previous season and re-invested for the next planting season.

5) Supporting government program related to the functioning of a fair market and price stabilisation of red onion produce: The immediate need for support from government program are the development of market institutions and price stabilization. At this moment, there was no program implemented yet related to the reform of market institution and price stabilization. There was a plan by the Ministry of Agriculture and Logistic Affairs of the Republic of Indonesia to absorb the red onion product from the farmers by setting the lowest reference price, but it did not yet implement. A Trade Minister Regulation has also enacted in 2016 on the price references for horticulture product but also has yet to be implemented.
The other supporting program needed by the farmers is about the wise and appropriate use of pesticides as the cost for this component of farming was the highest among other cost items. In the Lembah Gumanti alone found more than one-third (112 out of 313) of the agriculture inputs kiosk, providing inputs including pesticides. About half (12,750out of 25,622) of the total hand sprayers in the Solok District were used in Lembah Gumanti Subdistrict. In addition to hand sprayers there still 94 mist blower and power sprayer were used to apply pesticides. This figure indicated that the intensity of pesticides used the subdistrict. In this relation, there is a need for introducing sustainable technology and innovation for pest management in the context of healthy agriculture.

6) Availability of supporting infrastructures: In term of infrastructures support, the need are irrigation to deal with availability of water supply in the dry season and farms access road to minimize the cost of transporting the inputs to and the harvested product out of the farms. From the indepth interview, beside the unclear pattern of the season, the dry season can happen up to three months in a year.

The survey data showed that the majority of the farmers (80 percent) indicated that proper farm access road was not available, while another 20 percent of the farmers enjoyed better access road because the location of their farmlands closed to the district, rural, or settlement roads. In the case of irrigation infrastructure, none of the farmers having irrigation services, they rely more on rain and available natural flow. In dry season effort has been made by pumping water from the source. There is twelve small-scale water pumps use in the sub district.

7) The absence of digital platform which can facilitate marketing, agriculture extension and program for public support, and access to finance: The digital platform could provide an opportunity to help in dealing with the complex problems of horticulture farming. Majority of the farmers and other stakeholders used digital equipment/gadget to communicate among them. Some forms of communication between and among traders and farmers have to happen, however, it was not organized such that it could improve the marketing, extension, provision of accessible public supports, and financing scheme opportunities. The example of digital platform facilitating red onion marketing from Brebes (one of the red onion production center in Java) by Limakilo.id which could improve the income and livelihood of the farmers and retailers (including small shops) in the city has yet to develop in the highland of Solok District.

8) Synergy and partnership among the stakeholders not yet developed: There were three major stakeholders currently active and directly engaged in the red onion farming management (farmers, traders, and private company supplying chemical pesticides), while three other stakeholders (government agencies, financial institution, and university) were not directly engaged and played a supportive roles. Among the three major stakeholders, farmers were in the weakest position about traders and the private company supplying production inputs. Traders tended to control the market, distribution, price of red onion produce, while private company controls the supply price of chemical pesticides which is needed to protect the crop from 
harvest failure. Efforts to create and strengthen a positive synergy among major actor has yet to develop. Farmers' organization which potentially could strengthen the position of the farmers in interacting with two other major stakeholders were inactive. Addressing the need for synergy among major and supportive stakeholders will be key to improve red onion horticulture farming management in the future and an important part of integrated agriculture cluster area development.

\section{B. Discussion.}

This research attempting to understand the dynamics and of red onion horticulture farming which directed toward identifying key factors as elements to formulate enabling framework and setting for integrated and sustainable development of horticulture cluster area. The limited achievement by a government initiative to develop the agriculture cluster area indicated that some key elements were not yet part of the framework used by the government.

The results of the research have enabled the identification of key elements of the framework for developing an integrated red onion farming cluster area. The elements are related to (1) improving the role of government which was very minimum with regard price stabilization, (2) strengthening market institution for a more fair interaction between farmer producers and traders, (3) improving financial literacy of the farmers, (4) improving agriculture extension especially with regard to the wise and appropriate use of chemical inputs, (5) social capital development related to strengthening farmers organization, (6) developing mutually beneficial synergy and partnership among the stakeholders, (7) provision of supporting infrastructures especially farms access road and management and provision of irrigation water for dry season, and (8) development of digital platform to help improve communication and decision making in dealing with the complex problems.

The data showed the real condition in the field indicated that the ecosystem for integrated and sustainable development of the agriculture cluster area was not yet developed. Therefore, there is a need to develop an alternative framework for the future development of agriculture cluster area.

The alternative framework and setting need to respond to the weaknesses of the previous approach which characterized by the dominant role of the government, limited public funding support, less participatory, and insufficient support to the farmers and their organization to play major role in the agriculture cluster area development in synergy and partnership with other stakeholders. In this context, there is a need take into account the dynamics of, and all those key factors affecting red onion farming, as the elements in the formulation of enabling framework and setting.

The results of-of this research indicated that there is a need to give attention to the following three key factors: (1) improving red onion farming management, (2) strengthen bargaining position of the farmers in the market and price stabilization, and (3) to facilitate mutually beneficial synergy and partnership between the farmers and other strategic stakeholders (traders, government agencies, university and research institution). A careful look at those elements, they are firmly related to the existence and functioning of farmers' organization.

The first key area, improvement of red onion farming management, is related to building the capacity of both individual farmers and their organization. Better farming management capacity of the farmers and existence of functioning farmers organization closely related to production planning, joint selling and responding to market dynamics which can improve their bargaining position in the market [14], [15]. It is a key factor to enable them to play major in the development of integrated agriculture cluster area. Therefore, there is a need to make the formal existence of the group (as a local institution) more meaningful for the farmers.

The second area of concern is the bargaining position of the farmers which currently weak. Strengthening the bargaining position of the farmers not only need functioning farmers organization but also supporting policy and program from the government for fair market relations both about producing as well as inputs.

The third area which needs to put attention to is a platform for mutually beneficial synergy and platform. This is a platform which could facilitate major stakeholders with direct engagement and supporting stakeholders, all working together to develop agriculture cluster area which will strengthen the local economy.

\section{CONCLUSIONS}

This research attempted to develop an understanding of the dynamics of, identify key factors related to the dynamics of red onion horticulture farming management. These key factors would contribute to the elements of enabling framework and setting for integrated and sustainable development of agriculture cluster area in the highland of Solok District, West Sumatra. The dynamics of red onion farming affected by the key factors indicated that the farmers were in a weak position and ecosystem for integrated and sustainable horticulture cluster area was not yet developed.

In order to develop the enabling framework and setting, there is a need to put attention to the following elements: (1) improving the role of government which was very minimum with regard to price stabilization, (2) strengthening market institution for a more fair interaction between farmer producers and traders, (3) improving financial literacy of the farmers, (4) improving agriculture extension especially with regard to red onion horticulture farming management and the wise and appropriate use of chemical inputs, (5) social capital development related to strengthening farmers organization, (6) developing mutually beneficial synergy and partnership among the stakeholders, (7) provision of supporting infrastructures especially farms access road and management and provision of irrigation water for dry season, and (8) development of digital platform to help improve communication and decision making in dealing with the complex problems of red onion farming.

\section{ACKNOWLEDGMENT}

We would like to thank Andalas University Research and Community Engagement Institute (LPPM UNAND) for 
providing funding support for this research under Contract No. 11/UN.16.17/PP.RGB/LPPM/2018.

\section{REFERENCES}

[1] M. Friedman and M. Douglas, Agropolitan Development: Toward a New Strategy for Regional Planning in Asia. School of Architecture and Urban Planning, University of California, Los Angeles, 1975.

[2] A. Setyanto, Historical Perspective of Agriculture Cluster Area Development (in Indonesia language), in The Management of Agriculture Cluster Area Development, Bureau of Planning, Ministry of Agriculture Republic Indonesia, pp 25-54, 2015.

[3] P. Nugroho, Rural Industry Clustering toward Transitional RuralUrban Interface, IOP Conference Series: Earth and Environmental Science 158 (2018) 012055.

[4] L. Farhanah, Sucihatiningsih, D.W. Prajanti, Staretegies in Developing Agropolitan Area in Indonesia, Jurnal Ekonomi Pembangunan, 16 (2), Desember 2015, pp 158-165 (available online: http://journals.ums.ac.id).

[5] Suyitman and Sutjahjo. 2011. The Analysis of Agropolitan Area's Level of Development based on Cattle Livestock Farming as Priority Commodity at Perpat Village, Belitung District, Indonesia, Journal of Indonesia Livestocks, Vol. 13 (2), Juni 2011: 130-140.

[6] A. Setyanto, Cluster Approach in Agriculture Area Development, in The Management of Agriculture Cluster Area Development, Bureau of Planning, Ministry of Agriculture Republic Indonesia, 145-180, 2015.

[7] A. Prasetya, Suyadi, M. Bisri, Soemarno, Development Startegy of Sendang Agropolitan Area, Tulungagung, International Journal of Applied Sociology 2015, 5(3): 113-120, SAP 2015.

[8] E. Antriyandarti, M. Ferichani, S.W. Ani, Sustainability of PostEruption Socio-economic Recovery for the Community on Mount Merapi Slope through Horticulture Agribusiness Region Development (Case Study Boyolali District), Procedia Environmental Science, 17 (2013) 46-52, Elsevier, 2013.

[9] I. Rosyadi, D. Purnomo, Profitability and Efficiency of Red Onion Farming, Jurnal Ekonomi Pembangunan, 15(2), Desember 2014, 117-127.

[10] B.T. Suroyo, and W. Handayani, Development of Agropolitan Cluster Area in Kulonprogo District, Special Region of Yogyakarta, Jurnal Perencanaan Wilayah dan Kota (Journal of Regional and City
Planning), Vol 25, No. 3243-261, Desember 2014, SAPK ITB and IAP.

[11] Y. Kanchanoek and U. Aslam, Policy Schemes for the Transition to Sustainable Agriculture - Farmer Preferences and Spatial Heterogenity in Northern Thailand, Land Use Policy 78(2018) 227235, Elsevier.

[12] S.A. Andayani, Suhaeni, and Y. Sumekar, Shallot Agribusiness Value Chain in Lowland Area of Majalengka, West Java Province, Indonesia, International Journal of Agriculture Sciences, Volume 10, Issue 7, 2018, 5714-5720.

[13] A.W. Puspitasari, Farmer's Prosperity: How to Increase Farmer's Bargain Power (in Islamic Perspective), Procedia - Social and Behavioral Sciences 211 (2015) 455-460, Elsevier.

[14] A. Sorrentino, C. Russo, and L. Cacchiarelli, Strengthening Farmers' Bargaining Power in the New CAP, International Journal on Food System Dynamics, Proceeding in System Dynamics and Innovation in Food Networks 2017, 123-127.

[15] M. Innocent, Ranganathan, Sankaranarayanan, and $H$. Vasanthakaalam, Success Story of Implementing the Self-sustaining Agriculture Extension Systam in Rwanda, Journal of Agriculture Extension and Rural Development, Vol 10(9), 175-185, September 2018.

[16] R. Ranjan, Challenges to Farm Produce Marketing: A Model of Bargaining between Farmers and Middlemen under Risk, Journal of Agriculture and Resource Economics 42(3): 386-405, 2017.

[17] V. Raungpaka and P. Savetpanuvong, Information Orientation of Small-scale Farmers' Community Enterprises in Northern Thailand, Kasetsart Journal of Social Sciences 38(2017) 196-203.

[18] D.T. Gultom, Sumardjo, S. Sarwoprasodjo, and P. Muljono, The Roles of Cyber Extension Communication Media in Strengthening Horticulture Farmers in Facing Globalization in Lampung Province, Indonesia, International Journal of Science: Basic and Apllied Research, Volume 26, No. 2, 104-117, 2016.

[19] Dardak, Emil Elestianto. 2007. The Development of Agriculturebased Small Urban Area to Promote Rural Development: The Case of the cattle-Related Industries in Ampel Sub-district, Central Java. A Thesis Submitted for the Degree of Doctor Philosophy, Ritsumeiken Asia Pacific University, Beppu, Japan.

[20] Pretty, Jules. 2008. Agriculture Sustainability: Concepts, Principles and Evidences. Phol. Trans. R.Soc. B (2008) 363, 447-465.

[21] Kesavan, P.C. and M.S. Swaminathan. 2008. Strategies and Models for Agricultural Sustainability in Developing Asian Countries. Phil Trans. R. Soc. B (2008) 363, 877-891. 